IZA DP No. 10282

Longer School Schedules and Early Reading Skills: Effects from a Full-Day School Reform in Chile

Matias Berthelon

Diana Kruger

Veronica Vienne

October 2016 


\title{
Longer School Schedules and Early Reading Skills: Effects from a Full-Day School Reform in Chile
}

\author{
Matias Berthelon \\ Universidad Adolfo Ibañez \\ Diana Kruger \\ Universidad Adolfo Ibañez \\ and IZA \\ Veronica Vienne \\ University of Manchester
}

Discussion Paper No. 10282

October 2016

\author{
IZA \\ P.O. Box 7240 \\ 53072 Bonn \\ Germany \\ Phone: +49-228-3894-0 \\ Fax: +49-228-3894-180 \\ E-mail: iza@iza.org
}

Any opinions expressed here are those of the author(s) and not those of IZA. Research published in this series may include views on policy, but the institute itself takes no institutional policy positions. The IZA research network is committed to the IZA Guiding Principles of Research Integrity.

The Institute for the Study of Labor (IZA) in Bonn is a local and virtual international research center and a place of communication between science, politics and business. IZA is an independent nonprofit organization supported by Deutsche Post Foundation. The center is associated with the University of Bonn and offers a stimulating research environment through its international network, workshops and conferences, data service, project support, research visits and doctoral program. IZA engages in (i) original and internationally competitive research in all fields of labor economics, (ii) development of policy concepts, and (iii) dissemination of research results and concepts to the interested public.

IZA Discussion Papers often represent preliminary work and are circulated to encourage discussion. Citation of such a paper should account for its provisional character. A revised version may be available directly from the author. 
IZA Discussion Paper No. 10282

October 2016

\section{ABSTRACT \\ Longer School Schedules and Early Reading Skills: Effects from a Full-Day School Reform in Chile}

This paper analyzes the impact of longer school schedules on children's $2^{\text {nd }}$ grade reading comprehension skills in Chile. In a setting where families choose schools, we identify the causal effect of longer schedules with instrumental variables, using the local availability of full-day schools as an instrument. We find that lower-income families are more likely to choose full-day schools, and after controlling for selection, longer school schedules lead to an increase of 0.14 standard deviations in reading comprehension. Effects are heterogeneous, with greater benefits among children attending public (municipal) and urban schools, and among girls. We also find that the benefits of longer school days accumulate over time.

JEL Classification: $\quad$ I21, I28, I26, H43

Keywords: reading comprehension skills, full-day schooling, school schedules, SIMCE, Chile

Corresponding author:

Diana Kruger

Universidad Adolfo Ibáñez

Av. Padre Hurtado 750

Viña del Mar

Chile

E-mail: diana.kruger@uai.cl 


\section{Introduction}

It's impossible to dispute the relevance of literacy. It facilitates access to a formal education - which is an avenue to employability and higher quality employment. Literacy in adulthood also allows individuals to be more engaged and participate more fully in society: it is associated with better health outcomes, higher levels of trust in others, more participation in volunteer or community activities, and in feeling empowered about the capacity to impact society through participation in the political process (Sen, 2003; OECD, 2016).

Research in education has shown that it is critical that reading skills be mastered by children early in the education process (Sparks et al., 2014; Cunningham and Stanovich, 1997). Reading involves two functions: decoding (word recognition) and reading comprehension; if one of these is weak or missing, the process becomes more difficult. As early reading skills develop and become more automatic, word recognition becomes less demanding of cognitive resources and these are freed for other reading factors like vocabulary, content and form. If children struggle in the early part of the reading process, then language comprehension in the latter school years is hindered; this has been termed the "Mathew effects" in the education literature (Cunningham and Stanovich, 2001). ${ }^{1}$ At the same time, given the existence of complementarities in the development of skills (Cunha and Heckman, 2007), there is also evidence of spillover effects of reading skills onto learning in other areas (Borghans and Diris, 2014).

The benefits of early reading skills on latter educational success is also well documented. In a longitudinal study following students through $1^{\text {st }}$ and $2^{\text {nd }}$ grade, Alexander and Entwisle (1988) found that reading abilities from first grade have an impact across several outcomes in $2^{\text {nd }}$ grade. Fryer and Levitt (2006) found that black children enter $1^{\text {st }}$

\footnotetext{
${ }^{1}$ This term comes from the Biblical passage that describes a rich-get-richer and poor-get-poorer phenomenon. In the education context, children who master the early reading process of decoding will do better in the latter processes of reading and language comprehension, critical reading, etc., while children who struggle in the early years will continue to do worse.
} 
grade with disadvantages in reading and math skills relative to white students, and that the gap increases into $3^{\text {rd }}$ grade, even after controlling for a set of covariates. Effects persist in the long run as well, as much of the difference in high school students' reading abilities are a consequence of skills developed (or not) in the early grades of elementary school (Sparks et al., 2014; Mol and Bus, 2011; Hurry and Sylva, 2007; Cunningham and Stanovich, 1997). Since early reading abilities have an impact on later academic success, and if one believes the causal link between educational achievements and future opportunities and productivity in the labor market, accomplishing an adequate level of reading skills in the early years of primary school is important for future socio-economic opportunities and outcomes.

One of the factors that influence the development of reading skills in general and early skills in particular, is time spent in the classroom. Most of the empirical evidence indicates that full-day kindergarten improves students' cognitive abilities, including vocabulary and pre-reading skills. Using longitudinal data from the Early Childhood Longitudinal Study, Kindergarten Class of 1998-99" (ECLS-K 98), DeCicca (2007) and Loeb et al. (2007) find positive effects of full-day kindergarten on numeracy and pre-reading skills, and that the effects are heterogeneous across household income: children from lower-income households benefit more from the policy. Using longitudinal data from 188 schools offering kindergarten, Zvoch, Reynolds and Parker (2008) found that children attending full-day kinder experienced faster literacy competence, and that the policy was more efficient in smaller classrooms. ${ }^{2}$ Among older children, Graves (2011) analyzed a related policy that lengthened the school year calendar in California, and found that standardized test scores of underprivileged students increased as a result of the policy. However, less is known about the impact of increasing daily classroom time on academic outcomes of older children in the United States.

\footnotetext{
${ }^{2}$ Some find that the effects of full-day kindergarten are short-lived (Brownell et al., 2015) while one study found negative longrun effects of full-day kindergarten on vocabulary, pre-reading and numeracy skills (DeCicca and Smith, 2013).
} 
Several other countries have implemented policies that increase time in the classroom for primary and secondary students through longer school schedules, in an effort to improve educational achievements. For instance, longer schedules have been found to have positive effects on $6^{\text {th }}$ grade students' standardized tests in Italy (Battistin and Meroni, 2016) and among $10^{\text {th }}$ graders in Chile (Bellei, 2011), as well as on academic achievements among elementary students in $4^{\text {th }}$ and $6^{\text {th }}$ grade in Chile, Colombia and Uruguay (Valenzuela, 2005; Garcia, 2006; Hincapie, 2013; Cerdan-Infantes and Vermeersch, 2007). ${ }^{3}$ These studies analyzed the impact of greater classroom time on academic achievements of children aged between 10 and 16 years of age ( $4^{\text {th }}$ through $10^{\text {th }}$ grade, respectively) who already knew how to read at the time of the test. In this paper, we analyze the effect of longer school schedules on early reading comprehension skills acquired during the first stages of the reading process - specifically, among $2^{\text {nd }}$ grade students in elementary school in Chile, who are in the crucial, early years of the reading process.

School schedule reforms in other countries have been partial and targeted to vulnerable students, and they vary in terms of scope, population covered, and intensity (hours spend in the school). The Chilean reform is the only comprehensive extension of school schedules across an entire education system. ${ }^{4}$ The policy began in 1997 and extended the length of the school day by about 35 percent without increasing the length of the school year calendar, which amounted to an additional 1.5 to 2 hours of daily classroom time. Although the government did not mandate how the additional hours had to be used, most schools dedicated the additional hours to teaching language and math (DESUC, 2005). Since the Chilean education system allows families to choose any publicly funded school irrespective of their location of residence, we address selection into schools and

\footnotetext{
${ }^{3}$ Meyer and Van Klaveren (2013) found no effects of an experimentally designed short-term intervention that lengthened school days in a small group of schools in the Netherlands.

4 The reform targeted publicly funded elementary and secondary schools. Those schools represent more than 90 percent of total enrollment in the education system.
} 
identify the causal effect of longer instruction time with instrumental variables, exploiting the exogenous variation that families face in local access to full-day schools as an instrument. Our findings reveal that greater instruction time increases $2^{\text {nd }}$ grade students' reading comprehension skills. Attending a full day school increased SIMCE test scores by 0.14 standard deviations (s.d.). We also find that the effects of instruction time are heterogeneous: girls and children in public (municipal) schools experienced an increase of 0.19 s.d. as a result of the policy, with no statistically significant effects on boys or children in voucher schools; meanwhile, test scores of children in urban schools increased by 0.15 s.d., with no statistically significant impact on rural children. We are also able to estimate the accumulated effect of exposure to FDS, and find that children exposed to 1 year of FDS have better reading comprehension skills that non FDS students, and the difference is approximately 0.05 s.d. However, exposure to two years of FDS (more than) doubles the positive effects of one yeari.e. results suggest that there are cumulative effects of FDS on the development of reading skills, and that instruction time in both $1^{\text {st }}$ and $2^{\text {nd }}$ grade play a role in improving reading skills.

This paper contributes to the existing literature because it is the first to analyze the effect of greater classroom time on students' reading comprehension skills early in the learning process (measured at the end of $2^{\text {nd }}$ grade). Secondly, we analyze the effect of comprehensive reform that took place on a national scale, and we are able to explore whether the effects of classroom time accumulate during the first two years of elementary school. Furthermore, in line with previous studies, we analyze whether the effects of greater instruction time are heterogeneous across several dimensions.

The remainder of the paper is organized as follows. Section 2 describes the Chilean education system, the FDS reform, and the $2^{\text {nd }}$ grade standardized reading comprehension test 
(SIMCE). Section 3 describes our empirical framework. Section 4 describes our data and variables, and section 5 discusses our results. We close with concluding comments.

\section{The Chilean Education System and the 2nd Grade SIMCE Test}

Chile's general education system consists of 12 years of schooling that are divided into two levels: primary, which includes $1^{\text {st }}$ through $8^{\text {th }}$ grade, and secondary, which includes grades 9 through 12. Furthermore, the education system is characterized by school choice. Three types of school exist, defined by their funding scheme. First, there are public schoolsadministered at the municipal level that are funded by a per-student subsidy from the central government and from resources allocated by the municipality. Second, there exist privatesubsidized or voucher schools, which are privately owned, for-profit organizations that receive the same per-student subsidy from the central government as public schools, but which can charge additional fees to their students. ${ }^{5}$ Third, there are private schools that do not receive public funding and are allowed to freely set the fees they charge (Mizala and Romagera, 1999). Private and private subsidized schools can select students but public (municipal) schools cannot. 6

Within this context, and unlike public school systems in other countries, families in Chile are not restricted to a specific location or district when they choose a school because the government's per-student subsidy is independent of the family's municipality of residence. Families can enroll their children in the school of their choice, according to their preferences and financial capacity. This characteristic of Chile's education system introduces competition between publicly funded schools; in fact, schools' average results in national standardized tests—which are interpreted as a proxy for school quality—are published and publicized each

\footnotetext{
5 The fee charged to students is regulated and the government per-student subsidy is reduced as private fees increase.

${ }^{6}$ In this paper we will address only publicly funded schools-public and voucher-since they represent 92 percent of total enrollment, and because private schools did not have to comply with the full-day schedule reform that we analyze.
} 
year, and they are considered an important element in helping parents make informed decisions about the school they choose (Chumacero et al., 2011; Gallego and Hernando, 2009).

The SIMCE tests

Chile has a long history of measuring academic achievement with standardized tests, and the current evaluation system-referred to as SIMCE, for its Spanish acronym — was implemented in 1988. The SIMCE standardized tests measure students' achievements in academic subjects covered by the national education curriculum; the tests are given to all students of selected grades every year.7 With each SIMCE test, surveys are carried out to gather information on students' educational context: a survey is sent to students' parents, school administrators and students' teachers, to gather data on family socio-economic and demographic characteristics and on various school inputs. Parents' responses are voluntary, while teacher and administrator responses are mandatory. ${ }^{8}$

The general objective of the SIMCE tests is to provide information on schools' ability to meet the academic goals put forth in the national education curriculum, interpreted by the different stakeholders as a school's quality. Reading comprehension is a priority for education policy makers; however, discovering reading deficiencies by the end of $4^{\text {th }}$ grade might be too late for remedial programs to be successful. Thus, in 2012 an earlier reading test was introduced taken at the end of the $2^{\text {nd }}$ grade by all students. ${ }^{9}$ The $2^{\text {nd }}$ grade SIMCE only covers reading comprehension, and its objective is to measure early reading skills and identify schools with deficient outcomes. Following confidentiality guidelines, schools were informed

\footnotetext{
${ }^{7}$ As of 2016 , the SIMCE test will be applied yearly to all $4^{\text {th }}$ and $10^{\text {th }}$ grade students, and every other year to $6^{\text {th }}$ and $8^{\text {th }}$ grade students (alternating); it will be applied yearly to a sample of $2^{\text {nd }}$ grade students.

8 The 2nd grade SIMCE test did not include teachers' questionnaire.

${ }^{9}$ The school year runs from March to December in Chile, and SIMCE tests are given in October/November of each year.
} 
the average $2^{\text {nd }}$ grade SIMCE reading results, and the Ministry of Education would inform parents directly and confidentially if their child had not learned to read by the $2^{\text {nd }}$ grade. ${ }^{10}$

The SIMCE test scores are standardized at a mean score of 250 and standard deviation equal to 50. Table 1 presents the average $2^{\text {nd }}$ grade SIMCE scores by child's sex, type of school, and area of the school's location. It also reports test score for these categories by schools' FDS status. Columns (1) and (2) refer to all children for whom data is available. ${ }^{11}$ In line with findings in other countries, girls performed better than boys in the reading test; SIMCE scores are highest in private schools, followed by voucher and public schools, respectively; furthermore, children in urban schools performed better than those in rural areas.

In order to analyze the role of instruction time, we compared outcomes according to schools' FDS status; however, only voucher and public schools were required to subscribe to the full-day reform, and children in publicly-funded schools performed slightly worse than the national average (column (3) of Table 1). Within publicly funded schools, columns (5) and (6) reveal that on average, SIMCE scores were lower in FDS schools compared half-day schools. Since families in Chile are able to choose schools, it will be important to control for selection to be able to identify what effect, if any, the schedule has on early reading skills. The empirical strategy described below will address issues related to selection.

The Full-Day Schedule reform

Chile initiated a large-scale education reform in 1997 that included the increase of the amount of time students spent in the classroom without lengthening the school year-in other words, it increased the length of daily school schedules-and it came to be known as the

\footnotetext{
${ }^{10}$ Since private and private subsidized schools can select students, to avoid discrimination by schools, teachers and school administrators do not have access to individual student test scores; they are informed about the average results of each class and grade level at their school. Parents can request individual scores to the corresponding authorities, and they are may be informed about their children's results confidentially.

${ }^{11}$ The Education Quality Assurance Agency did not include all schools in the data set they provided; they omit small schools and/or schools where identification of individual children was deemed possible. Our data represents $86 \%$ of all children who took the test in 2012. Additionally, the Ministry of Education did not provide FDS status information for private schools.
} 
Full Day Schooling (FDS) reform. It mandated that all primary and secondary schools that receive public funds_-public or voucher-must offer a full-day schedule by 2007 and 2010, respectively, and the change to full-day schedules could be implemented gradually within a school. Additionally, the FDS law mandated that all publicly funded schools created after 1997 must initiate operations as full-day schools.

The main objective of the FDS reform was to improve school quality in Chile. One school input in students' learning process is instruction time; the FDS reform is based on the premise that more instruction time leads to higher learning achievements by students. If so, then one should observe that students in schools with longer school schedules have higher academic achievements, which can be proxied by results in standardized tests. As discussed earlier, former evaluations of the FDS reform find positive effects of longer schedules on education achievements for older children $\left(4^{\text {th }}, 6^{\text {th }}\right.$ and $10^{\text {th }}$ grade).

The implementation of the FDS reform was not immediate but gradual, due to infrastructure and financial constraints. The program had operational and infrastructure costs. The operational component included variable costs that increased as a result of lengthening the amount of time children spend in school; for example, teachers' salaries, administrative costs, and the provision of school lunches. To cover operational costs, the perstudent subsidy regularly paid to all public and voucher schools increased by about $20 \%$. The most important expense (and constraint) associated with a full-day school is the expansion of schools' infrastructure to accommodate, in many cases, twice the number of students at any given time. Schools that wished to change their operations to FDS competed for public infrastructure funds through an application process with the Ministry of Education, where they submitted their academic plans and requested the required funds to operate under the full day regime. 
The Ministry of Education did not allocate FDS infrastructure funds randomly, they followed administrative criteria that prioritized schools with pre-existing deficits in infrastructure or that were located in areas of socio-economic vulnerability. The first schools that entered the program were schools with relatively low switch costs, i.e., schools with excess capacity, because they didn't need to apply for the infrastructure funds.

The FDS law stipulates that in primary schools, weekly academic hours have to increase from 30 to 38 hours in grades 3 to 6 , and from 33 to 38 hours in grades 7 th through 8th (García Huidobro and Concha, 2009).12 This amounts to an additional 1.5 to 2 hours of daily classroom time. In addition, there were also increases in time allocated for recesses and lunch, so that time spent at school increased by about 35 percent in primary schools without increasing the number of days in the academic calendar. According to the reform, schools could gradually phase-in all their grade levels into the full-day program, and they could follow any pattern they chose. The only restriction was that all students in a given grade level had to switch at the same to the FDS regime. ${ }^{13}$

Schools did not have to switch $1^{\text {st }}$ and $2^{\text {nd }}$ grades into the full-day schedule, it was optional. However, by 2012 , approximately 60 percent of $1^{\text {st }}$ and $2^{\text {nd }}$ grades of publicly funded schools and 40 percent of $1^{\text {st }}$ and $2^{\text {nd }}$ grade enrollment, were under the full-day regime (Table 2). ${ }^{14}$ This is due to the fact that, as discussed above, schools that changed to the FDS schedule had lower switch costs, and they had lower enrollment in general. Table 2 also reveals that the implementation of the reform has been heterogeneous across Chile's regions, ranging from coverage of 10 percent of schools and 11 percent of students in the Antofagasta and Magallanes regions, respectively, to 75 percent of all schools and 89 percent of enrollment in

\footnotetext{
12 One academic hour is equivalent to 45 minutes.

${ }^{13}$ For instance, it was possible for a primary school to offer FDS for 5th through 8th grades, and not for 3rd and 4th grade. However, if a grade level is full-day, all its classrooms within that grade level have to be offered as FDS.

${ }^{14}$ Although the reform mandated that schools had to implement FDS schedules by 2010, there were no enforcement mechanisms, so that by the time of the deadline a large fraction of schools had not complied. There is still a large fraction of schools that have not implemented the reform.
} 
the Los Rios region. We also observe significant differences in the coverage of the program by area (urban vs. rural) and funding scheme (public vs. voucher), with FDS achieving larger levels of implementation in rural areas and in public schools.

\section{Empirical framework}

We estimated the effects of full-day school schedules on early reading comprehension skills, as measured by Chile's $2^{\text {nd }}$ grade SIMCE test. Our empirical strategy is motivated by the fact that in Chile, families that attend publicly-funded schools may send their child to any school of their choice, so that attendance to full-day schools is a choice that may be correlated with family background and inherently, a child's reading ability. Thus, a simple linear regression framework would not capture a causal effect of school day length, because the OLS coefficient would suffer from selection bias. To address this problem, our empirical strategy is instrumental variables. The instrument must be exogenous to individual reading test scores and be correlated with the family's school choice.

The first stage of our instrumental variables estimation is the following:

$$
F D S_{i j c}=\gamma^{\prime} X_{i}+\beta^{\prime} S_{j}+\pi Z_{c}+\omega_{i j c}
$$

where $F D S_{i j c}$ is a variable that indicates whether child $i$ attending school $j$ in municipality $c$

attends a full-day school; $X_{i}$ is a vector of the child's individual and family characteristics; $S_{j}$ is a vector of school characteristics, including school quality variables the year prior to the student's enrollment in her school; the instrument is $Z_{c}$, and $\omega_{i j c}$ is an idiosyncratic error term. The parameter $\pi$ measures the effect of the instrument on the family's decision to enroll their child in a full-day school.

Accordingly, our second stage is the following:

$$
y_{i j c}=\gamma^{\prime} X_{i}+\beta^{\prime} S_{j}+\rho F \widehat{D} S_{i j c}+\varepsilon_{i j c}
$$


where $y_{i j c}$ is the reading comprehension test outcome of student $i$, in school $j$ in municipality c. Our policy variable of interest is enrollment in a full day school; $F \widehat{D} S_{i j c}$ is the instrumented probability that the child enrolls in a full-day school, and $\varepsilon_{i j c}$ is a idiosyncratic error term. As long as the exogeneity and relevance assumptions of the instrument are met, the parameter $\rho$ measures the causal effect of longer school schedules on early reading skills, since it captures the effect of exogenous variations in full-day schooling on the student's test scores.

Our instrument is the availability of schools that offered full-days in first and second grades in the municipality where the student lives, the year before the student's enrollment in first grade. We use the supply of FDS schools at the municipal level because it is the most disaggregated geographical measure available in our data. ${ }^{15}$ This variable should be an important determinant in the family's decision between half or full-day schools, since a larger local supply of full-day schools should be positively correlated to the family's decision in favor of longer school days. Previous literature has demonstrated that parents in Chile choose schools that are near their homes-especially when they are in primary school—so that local availability of FDS schools is an appropriate proxy that influences parents' preferences (Chumacero et al., 2011; Gallego and Hernando, 2009). ${ }^{16}$

At the same time, the local availability of FDS schools is exogenous from the family's perspective, so that it is reasonable to assume that the instrument is uncorrelated with the error term in equation (2) once we have controlled for all individual, family, and school level variables, including school quality. ${ }^{17}$

\footnotetext{
${ }^{15}$ Chile had 15 administrative regions and 344 municipalities in 2012.

${ }^{16}$ In our data, 90 percent of 2 nd grade students attend school in the same municipality as where they live.

${ }^{17}$ The school system is highly decentralized in Chile and most school principals make decisions independently of other schools. Thus, the FDS program was taken up at different rates across Chilean administrative regions and municipalities, which generated regional variation across time that was exogenous to parents' school choice decisions.
} 


\section{Data and Variables}

We construct our data set from three sources. The first is the student-level $2^{\text {nd }}$ grade SIMCE test results, which provides the measure of our dependent variable of interest. Secondly, we obtained data on the surveys sent to parents and school administrators, and thirdly, the administrative data on the evolution of the full-day school reform. The first two data sets were provided by the Ministry of Education's Education Quality Assurance Agency, and the third data set is publicly available from the Ministry of Education website.

Our dependent variable $y_{i j c}$ is the student's individual score on the SIMCE reading comprehension exam, taken by Chile's second graders for the first time in 2012. The data set we obtained included approximately 207, 000 children, which represents 86 percent of all children who took the exam. Since the FDS law applies only for publicly funded schools, we analyzed $2^{\text {nd }}$ grade children that attended municipal or voucher schools in 2012, representing 92 percent of total national enrollment. The explanatory variables in vector $X_{i}$ come from a survey sent to parents the day of the SIMCE test, while school information in $S_{j}$ and the instrument $Z_{c}$ comes from data provided by the Ministry of Education.

Individual variables include a set of dummy variables for child's sex (equals 1 if male), whether the child attended pre-kinder; whether she attended kinder; whether the child repeated first or second grade; and whether the child was new to the school in 2012. Family characteristics include parents' income (variable with four categories for average monthly income: below US\$422, between US\$422-\$632, between US\$633-\$1,053 and above $\$ 1,053$ ), parents' education (years of schooling completed), and dummy variables controlling for region of residence.

The school-level characteristics include our variable of interest-FDS status-which we construct as a dummy variable that equals one if the school had full-day schedules in first 
and second grade. ${ }^{18}$ We also controlled for the school's total enrollment (in hundreds of students), class size, a dummy variable for whether the school is public (municipal), and a dummy variable for whether the school is in a rural area. We also controlled for school quality by including schools' 4th grade SIMCE test scores (in math and language) from years 2011 and 2012.

Our instrument is the share of schools at the municipal level that offered full-day schedules in first and second grade. ${ }^{19}$ Since most parents in Chile choose a school for their child's first grade, and in our sample children enrolled in first grade in 2011, this means parents made their decisions in 2010. We constructed our instrument using information on full-day school supply from 2009, which would have been the relevant information used by children's parents. ${ }^{20}$ Table 3 presents summary statistics for all children in our sample as well as by FDS status. As we observed previously, children who attend full-day schools have lower reading comprehension skills, measured by SIMCE test scores. We observe that part of the difference in test scores is due to differences in observed characteristics of students: children in half-day schools have slightly better previous academic achievements, measured as attendance to preschool and grade repetition. We also observe large differences in family background characteristics: children in half-day schools have parents with higher levels of education and higher income, they are more likely to be in voucher schools, school quality is higher (measured by $4^{\text {th }}$ grade SIMCE test scores), and they are less likely to be in rural areas. These descriptive statistics suggest that controlling for selection is important in order to measure causal effects of the FDS policy. Furthermore, if we expect longer schedules to have a

\footnotetext{
${ }^{18}$ More specifically, to match children's actual exposure to the FDS program, we defined a school as FDS if it offered a full-day schedule in $1^{\text {st }}$ grade in 2011 (when the majority of children in our sample were enrolled in $1^{\text {st }}$ grade) and in $2^{\text {nd }}$ grade in 2012 , which is the year of the $2^{\text {nd }}$ grade reading comprehension test.

${ }^{19}$ More than $91 \%$ of schools offered either both grades as FDS or neither of them.

${ }^{20}$ We also performed estimations using school FDS data from 2010 and results did not change.
} 
positive effect, but it is children from worse socio-economic conditions that are choosing fullday schools, then estimates that do not control for selection will be biased towards zero.

\section{Results}

We estimated the effects of longer school schedules on children's reading comprehension skills following the empirical methodology described above, for the entire sample and for different groups to study if the effects were heterogeneous. All estimations control for heteroskedasticity and errors are clustered at the school level. We present OLS estimates as a baseline/reference point in Table 4, which includes results for the full sample of 2 nd grade children. As shown by results in column 1, the effect of our variable of interest, longer school schedules or FDS, is zero with the OLS estimations. We expect this estimate to be biased towards zero because students in FDS schools tend to have individual, family and school characteristics that are generally associated with lower academic achievement.

\section{First stage}

Table 4 also reports results from the first-stage of the IV estimations (column 2). We observe that the instrument-municipal supply of FDS schools in $1^{\text {st }}$ and $2^{\text {nd }}$ grade-has a large, significant impact on the probability that families choose a full-day school. This is observed by the point estimate in the regression and the F-statistic of the excluded instrument. Figure 1 also plots the predicted probability of enrollment in a school with fullday $1^{\text {st }}$ and $2^{\text {nd }}$ grade-i.e., predicted values of equation (1) —and its relationship to local supply of FDS schools (after controlling for individual, family, and school characteristics). Panel A plots individual probabilities of FDS enrollment, and Panel B plots average probability of enrollment aggregated at the municipal level. These graphs confirm that there is a positive correlation between the instrument, local FDS supply, and the probability of attending an FDS 
school, suggesting that the instrument is relevant. In terms of the other control variables in column (2), as suggested by the descriptive statistics, our estimation confirms that children with more disadvantaged backgrounds are more likely to attend to FDS schools.

\section{Second Stage Results}

As indicated previously, when we do not account for selection, FDS does not affect test scores. However, once we control for selection into FDS schools, the effect of longer schedules on early reading skills is positive and, economically and statistically significant: attending a full-day school leads to almost 7 additional points on the 2nd grade SIMCE-equivalent to about 0.14 standard deviations (column (3) of Table 4). These results reveal that OLS estimates are biased towards zero, and that the selection bias is large. Additionally, all other point estimates are stable across both estimations.

Among the effects of other control variables, we find that boys obtained lower reading comprehension scores than girls (difference of about 0.2 s.d.), pre-school attendance had no significant impact (probably because almost all children attend pre-kinder and kinder in Chile), children who repeated 1 st or 2 nd grade obtained lower test scores ( 0.29 s.d.), and children who were new to the school in 2nd grade obtained slightly lower test scores $(0.03$ s.d.). An additional year of both mother and father's education is correlated with better reading comprehension test scores (0.02 s.d.), and family income is positively related to test scores. We also find that children in municipal schools obtained lower test scores (0.04 s.d.), and that children who attend larger schools performed slightly better. Furthermore, school quality -as proxied by $4^{\text {th }}$ grade SIMCE scores in the last two years-is correlated to better performance by children in the $2^{\text {nd }}$ grade test. Class size and rural location were not correlated with test scores. 


\section{Heterogeneous effects}

Table 5 summarizes the heterogeneous impact of FDS attendance on early reading skills, depending on the child's sex, school type (municipal or voucher) and school location (urban or rural). As in the baseline model, we find that in each first stage of these regressions, the instrument is highly significant and the F-statistic is large-clearly above the traditional benchmark of 10, as suggested by Stock, Wright, and Yogo (2002). In the second stage we find that full-day school schedules have positive effects on both boys and girls, however, they are statistically significant only for girls, who experienced an increase of 9.4 points (equivalent to 0.19 standard deviations) compared to other girls in non-FDS schools. In terms of type of schools, we find large and significant effects among $2^{\text {nd }}$ graders attending municipal schools, with longer school schedules leading to 9.2 more points on the SIMCE test (0.19 standard deviations). No significant effect is found on early reading skills among children attending voucher schools. Finally, we find positive effects on children attending to both urban and rural schools, although the effects are only statistically significant for urban areas, with FDS schedules increasing test scores by 7.5 points or 0.15 standard deviations. Overall, our results reveal that the full day policy had heterogeneous effects, with large benefits on more vulnerable students in municipal schools, and on girls.

\section{Exposure to full-day schools}

In our baseline estimations, we defined a school as full-day if both $1^{\text {st }}$ and $2^{\text {nd }}$ grade were under the FDS regime. Administrative data reveals that by 2012, most schools that entered the FDS program in the first two years of elementary school had switched both grades to the full-day schedules, or neither. In other words, most children in our sample had either two years of full-day exposure, or 0 years. However, some children experienced the change to the full-day regime only when they reached $2^{\text {nd }}$ grade, which implies that they were exposed to FDS for one year. 
Although there are few children under this scenario, we can use this variation to analyze a more continuous measure of exposure to full-day schedules and explore whether effects accumulate over time. We explored whether $2^{\text {nd }}$ graders that were exposed to 2 years of longer schedules (in $1^{\text {st }}$ and $2^{\text {nd }}$ grade) had better test scores than $2^{\text {nd }}$ graders that were exposed to full-day schooling only in the $2^{\text {nd }}$ grade (the year of the test).

We report results from these estimates in Table 6, finding that the effects of longer instruction time appear to accumulate over time: children with one year of the FDS program had better test scores than children not under the full-day regime, but the magnitude of the effect is about half of the effect of attending longer school schedules for two years. Column (1) of Table 6 indicates that compared to similar children without full-day schooling, children with one year of full-day schooling obtained 2.7 additional points ( 0.05 s.d.) on the SIMCE reading comprehension test while children exposed to two years of longer school days obtained 6.7 additional points $(0.14$ s.d.). Table 6 also reveals that that in many cases the effect of 1-year exposure is not precisely measured, probably due to the fact that since few children received 1 year of full-day instruction time and therefore there is not sufficient explanatory power in that variable to identify the effects.

\section{Concluding comments}

In this paper, we analyzed the impact of full-day school schedules on $2^{\text {nd }}$ grade students' outcomes in a standardized reading comprehension exam. Our sample included the population of children enrolled in $2^{\text {nd }}$ grade in 2012 in publicly funded schools in Chile, and we estimated heterogeneous effects across school location, school types (public (municipal) vs. private-subsidized) and across students' sex. We estimated a causal effect of the policy with instrumental variables, which controls for selection that stems from school choice in the 
Chilean education system. Exogenous local access to full-day schools was used as an instrument, and tests suggest that our instrument is not weak.

Our results reveal that longer school schedules improve early reading comprehension skills among Chilean children enrolled in $2^{\text {nd }}$ grade. The average effect is positive and significant: children enrolled in FDS schools obtained reading scores that were 0.14 standard deviations higher than half-day schools, after controlling for selection. We also find that the policy has heterogeneous effects benefiting more vulnerable students: among children of municipal schools, full-day schedules lead to an increase in the reading comprehension exam by 0.19 standard deviations, with no statistically significant impact among children in voucher schools. The policy also had a stronger impact on girls ( 0.19 standard deviations) compared to boys, on whom no effect was found. We also find that exposure to full-ay schooling is important: relative to children that have attended half-day schools in $1^{\text {st }}$ and $2^{\text {nd }}$ grade, being exposed to one year of a full-day regime led to an increase of 0.05 standard deviations on the $2^{\text {nd }}$ grade reading test, whilst two years of exposure led to an increase of 0.14 standard deviations. These results suggest that the effects of longer school schedules accumulate over time, at least during the first two years of elementary school.

The findings in this paper reveal that time spent in school has a positive impact on the reading process in its critical early phase. Although there is no comprehensive, systematic information on the use of the additional time that children spent in school, evaluations of the FDS policy indicate that in most schools spent the additional time in the classroom (DESUC, 2005). To the extent that schools used additional hours teaching subjects on the national education curriculum, it is possible to interpret the results as the effects of greater instruction time. If so, then our study suggests that greater instruction time has benefitted reading comprehension abilities of young Chilean children. 
Our results are in line with findings of the impact of full-day kindergarten in the United States (DeCicca, 2007; Loeb et al., 2007; Zvoch, Reynolds y Parker, 2008), as well as with other studies that evaluated the impact of longer school days on primary school students (Battistin and Meroni, 2016; Hincapie, 2016; Valenzuela, 2005). However, The magnitude of the effects of the FDS policy that we find are higher than those found in Bellei (2010) for Chile (0.14 sd compared to $0.05-0.07 \mathrm{sd})$. Whereas we analyze the impact of the reform on $2^{\text {nd }}$ grade students in 2012, Bellei (2010) analyzed the reform's effect on $10^{\text {th }}$ graders in a subgroup of schools between 2001 and 2003. The difference in results raises interesting questions. One possibility, for instance, is that the positive effect of longer schedules is stronger among younger children and that the effect diminishes over time. Another possibility, is that because of the timing of Bellei's (2010) evaluation (2001-2003), the implementation of the policy was still in their initial stages, and early adopters of the policy were adjusting to its implementation and problem solving (space, infrastructure, human resources, food provision, etc.) (DESUC, 2001), so that the potential positive effects had not been fully realized.

Although this paper does not provide a definite answer to these questions, we find some evidence that there might be accumulated effects of the policy that depend on the level of exposure to the policy over time. However, further research is needed to examine how lasting the effects of the FDS are, and the potential long term effects of being exposed to fullday schooling over larger periods of time. Research using longitudinal data on children exposed to the FDS reform would contribute to shed light over these still unanswered questions. 


\section{Acknowledgements}

Part of the data used in this paper was provided by the Agencia de Calidad de la Educación; authors thank the Agencia de Calidad de la Educación for access to the information. All results are responsibility of the authors and in no way represent the views of the Agency. Berthelon and Kruger received financial support from Chile's National Committee of Scientific and Technological Research (Comisión Nacional de Investigación Científica y Tecnológica, CONICYT), through FONDECYT Project No. 1120882. We thank seminar participants of at the departments of economics of Oregon State University, Universidad de Chile, Universidad de Santiago, CEA-Universidad de Chile, Universidad Adolfo Ibáñez Business School (Viña del Mar), Universidad Adolfo Ibáñez School of Government, and Annual Meetings of the Chilean Economics Society 2016. 


\section{References}

Alexander, K. L., Entwisle, D. R., Blyth, D. A., \& Mcadoo, H. P. (1988). Achievement in the First 2 Years of School: Patterns and Processes. Monographs of the Society for Research in Child Development, 53(2), 1-157.

Battistin, E., Meroni, E.C.(2016). Should we increase instruction time in low achieving schools? Evidence from Southern Italy. Economics of Education Review 55: 39-56, ISSN 02727757, http://dx.doi.org/10.1016/j.econedurev.2016.08.003.

Bellei, C. (2009). Does lengthening the school day increase students' academic achievement? Results from a natural experiment in Chile. Economics of Education Review, 28(5), 629640. doi:10.1016/j.econedurev.2009.01.008

Borghans, L., Diris, R. (2014). Allocating Instruction Time: How Language Instruction Can Affect Multiple Skills. Journal of Human Capital 8(2): 161-198. DOI: 10.1086/677188

Brownell, M. D., Nickel, N. C., Chateau, D., Martens, P. J., Taylor, C., Crockett, L., ... \& Goh, C. Y. (2015). Long-term benefits of full-day kindergarten: a longitudinal population-based study. Early child development and care, 185(2), 291-316.

Cerdan-Infantes, P., \& Vermeersch, C. (2007). More Time Is Better: An Evaluation Of The Full Time School Program In Uruguay. World Bank Policy Research Working Paper. Impact Evaluation Series. The World Bank.

Chumacero, R.A., Gomez, D., Paredes, R.D. (2011). I would walk 500 miles (if it paid): Vouchers and school choice in Chile. Economics of Education Review 30.5: 1103-1114.

Cunha, F., \& Heckman, J. (2007). The Technology of Skill Formation. American Economic Review 97(2): 31-47. DOI: 10.1257/aer.97.2.31

Cunningham, A. E.; Stanovich, K.E. (1997). Early reading acquisition and its relation to reading experience and ability 10 years later. Developmental Psychology 33(6): 934945. 
Cunningham, A. E., \& Stanovich, K. E. (2001). What Reading Does for the Mind. Journal of Direct Instruction I, (2), 137-49.

DeCicca, P. (2007). Does full-day kindergarten matter? Evidence from the first two years of schooling. Economics of Education Review, 26(1), 67-82.

DeCicca, P., \& Smith, J. (2013). The long-run impacts of early childhood education: Evidence from a failed policy experiment. Economics of Education Review, 36, 41-59.

Dirección de Estudios Sociológicos (DESUC). (2001). Informe Final “Estudio de Evaluación Jornada Escolar Completa." Santiago de Chile.

Dirección de Estudios Sociológicos (DESUC). (2005). Informe Final “Evaluación Jornada Escolar Completa." Santiago de Chile.

Fryer, R. G., \& Levitt, S. D. (2006). The black-white test score gap through third grade. American Law and Economics Review, 8(2), 249-281.

Gallego, F. A., and Andrés Hernando. "School choice in Chile: Looking at the demand side." Pontificia Universidad Catolica de Chile Documento de Trabajo 356 (2010).

García, Á. (2006). Evaluación del Impacto de la Jornada Escolar Completa. Mimeo. Universidad de Chile.

García-Huidobro, J. E., \& Concha, C. (2009). Jornada escolar completa: la experiencia chilena. Mimeo.

Graves, J. (2011). Effects of year-round schooling on disadvantaged students and the distribution of standardized test performance. Economics of Education Review, 30(6), 1281-1305.

Hincapie, D. (2016). Do Longer School Days Improve Student Achievement?: Evidence from Colombia. IDB Working Paper Series (Social Sector. Education Division); IDB-WP-679. Hurry, J. \& Sylva, K. (2007). Long-term outcomes of early reading intervention. Journal of Research in Reading, 30: 227-248. 
Loeb, S., Bridges, M., Bassok, D., Fuller, B., \& Rumberger, R. W. (2007). How much is too much? The influence of preschool centers on children's social and cognitive development. Economics of Education Review, 26(1), 52-66.

Meyer, E., \& Van Klaveren, C. (2013). The effectiveness of extended day programs: Evidence from a randomized field experiment in the Netherlands. Economics of Education Review, 36, 1-11.

Mizala, A., \& Romaguera, P. (1999). School Performance and Choice: The Chilean Experience. The Journal of Human Resources, XXXV(2), 392-417.

Mol, S.E., \& Bus, A. (2011). To Read or Not to Read: A Meta-Analysis of Print Exposure From Infancy to Early Adulthood. Psychological Bulletin 137(2): 267-96.

OECD (2016), Skills Matter: Further Results from the Survey of Adult Skills, OECD Skills Studies, OECD Publishing, Paris.

Sen, Amartya (2003). Reflections on Literacy. In: Literacy as Freedom: A UNESCO RoundTable. Paris: UNESCO Publishing.

Sparks, R.L., Patton, J. \& Murdoch, A. (2014) Early reading success and its relationship to reading achievement and reading volume: replication of ' 10 years later'. Reading and Writing 27: 189-211. doi:10.1007/s11145-013-9439-2

Stock, J. H., Wright, J. H., \& Yogo, M. (2002). A Survey of Weak Instruments and Weak Identification in Generalized Method of Moments. Journal of Business \& Economic Statistics, 20(4), 518-529.

Valenzuela, J. P. (2005). Partial Evaluation of a Big Reform in the Chilean Education System: From a Half Day to a Full Day Schooling. Mimeo. University of Michigan.

Zvoch, K., Reynolds, R. E., \& Parker, R. P. (2008). Full-day kindergarten and student literacy growth: Does a lengthened school day make a difference? Early Childhood Research Quarterly, 23(1), 94-107. 
Figure 1: Predicted probability of attending an FDS school in 2012

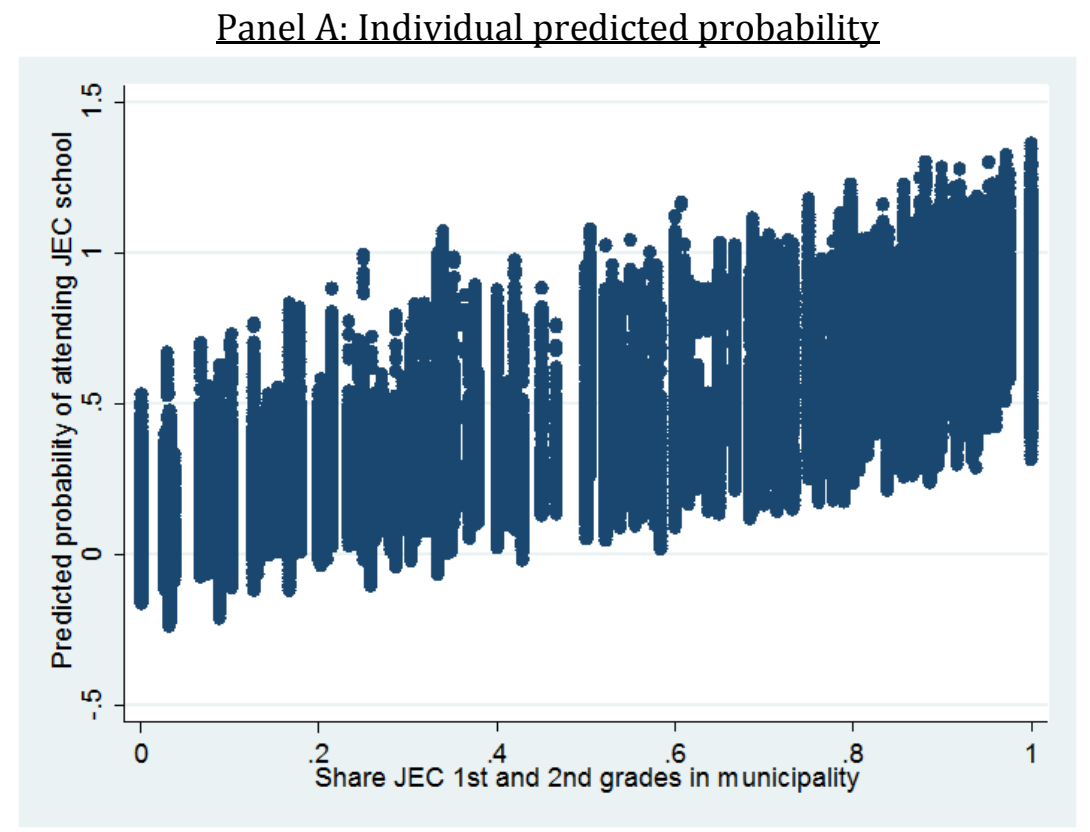

Panel B: Average predicted probability in the municipality

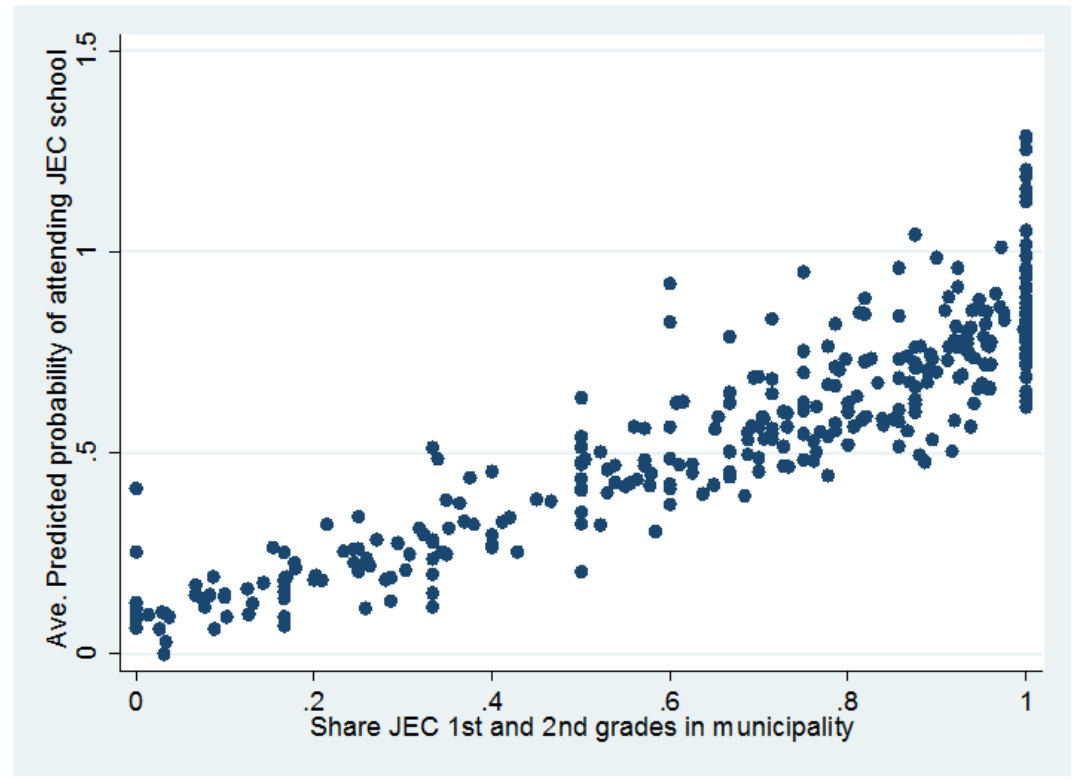

Panel A shows individual predicted probabilities of attending a FDS school in 2012 from first stage estimations reported in Table 4, column 2. Own estimates from data provided by the Education Quality Assurance Agency (Agencia de Calidad de la Educación). Control variables: municipal share of FD schools (1st and 2nd grade), child's sex, whether child attended pre-kinder or kinder, whether child repeated 1st or 2nd grade, new student in 2nd grade, mother and father's education, family income, dummy for municipal school, school enrollment, class size, school quality (proxied by 2011 and 2012 language and math SIMCE scores), dummy for rural location, and region fixed effects. Panel B reports average of individual predicted probabilities of attending a FDS school by municipality. 
Table 1. Readings skills of Chilean students in 2nd grade: average SIMCE score for FDS and non-FDS schools by sex, type of school, and area (2012)

\begin{tabular}{|c|c|c|c|c|c|c|c|c|}
\hline Students in: & $\begin{array}{l}\text { All schools } \\
\qquad(1)\end{array}$ & $\begin{array}{l}\mathrm{N}^{\circ} \text { obs. } \\
\text { (2) }\end{array}$ & $\begin{array}{l}\text { Publicly } \\
\text { funded } \\
\text { schools } \\
\text { (3) }\end{array}$ & $\begin{array}{c}\mathrm{N}^{\circ} \text { obs. } \\
(4)\end{array}$ & $\begin{array}{l}\text { FD schools } \\
\text { (5) }\end{array}$ & $\begin{array}{l}\text { Non-FD } \\
\text { schools } \\
\text { (6) }\end{array}$ & $\begin{array}{c}\text { Difference } \\
\text { in means } \\
(7)\end{array}$ & $\begin{array}{c}\text { t-test diff. in } \\
\text { means (p-value) } \\
(5)-(6) \\
(8)\end{array}$ \\
\hline Total & 250.4 & 207,326 & 247.6 & 190,045 & 241.8 & 250.3 & -8.5 & 0.000 \\
\hline \multicolumn{9}{|l|}{ Sex } \\
\hline Boys & 245.3 & 105,023 & 242.3 & 96,177 & 236.2 & 245.2 & -9.0 & 0.000 \\
\hline Girls & 255.7 & 102,303 & 253.0 & 93,903 & 247.7 & 255.6 & -7.9 & 0.000 \\
\hline \multicolumn{9}{|l|}{ Type of school } \\
\hline Public & & & 238.8 & 75,282 & 237.8 & 239.7 & -1.8 & 0.000 \\
\hline Voucher & & & 253.4 & 114,763 & 248.2 & 254.7 & -6.5 & 0.000 \\
\hline Private & 282.3 & 16,959 & & & & & & \\
\hline \multicolumn{9}{|l|}{ Area } \\
\hline Urban & 251.6 & 188,176 & 248.6 & 171,229 & 243.0 & 250.7 & -7.7 & 0.000 \\
\hline Rural & 238.8 & 19,150 & 238.3 & 18,816 & 238.4 & 237.0 & 1.4 & 0.171 \\
\hline
\end{tabular}

Own estimates from data provided by the Education Quality Assurance Agency (Agencia de Calidad de la Educación). SIMCE data is 2nd grade SIMCE Reading Comprehension test given in 2012. 
Table 2. FDS implementation in Chile by region, type of school and area (2012)

\begin{tabular}{|c|c|c|c|}
\hline & \multicolumn{2}{|c|}{ FDS in $1^{\text {st }} 2^{\text {nd }}$ grade } & \multirow{2}{*}{$\begin{array}{l}\text { Share of national } \\
\text { enrollment in 1st- } \\
\text { 2nd grade }\end{array}$} \\
\hline & Schools (\%) & Enrollment (\%) & \\
\hline \multicolumn{4}{|l|}{ Region } \\
\hline Arica y Parinacota & 57.2 & 67.1 & 1.4 \\
\hline Tarapaca & 48.4 & 52.3 & 2.2 \\
\hline Antofagasta & 9.7 & 16.5 & 3.7 \\
\hline Atacama & 19.1 & 44.1 & 1.9 \\
\hline Coquimbo & 51.8 & 71.4 & 4.3 \\
\hline Valparaíso & 31.1 & 44.2 & 9.7 \\
\hline Libert. Gral. Bdo. O'Higgins & 37.8 & 59.3 & 5.3 \\
\hline Maule & 48.1 & 71.6 & 5.9 \\
\hline Biobío & 39.1 & 59.6 & 11.8 \\
\hline La Araucanía & 70.0 & 83.7 & 5.8 \\
\hline Los Lagos & 61.9 & 84.5 & 5.2 \\
\hline Los Ríos & 75.2 & 88.6 & 2.2 \\
\hline Aysen & 66.4 & 82.5 & 0.7 \\
\hline Magallanes & 3.5 & 11.3 & 1.0 \\
\hline Metropolitana & 21.7 & 23.2 & 38.7 \\
\hline \multicolumn{4}{|l|}{ Type of school } \\
\hline Public (municipal) & 56.0 & 76.1 & 38.3 \\
\hline Voucher & 25.4 & 37.8 & 54.3 \\
\hline \multicolumn{4}{|l|}{ Area } \\
\hline Urban & 28.7 & 32.7 & 88.7 \\
\hline Rural & 86.1 & 91.5 & 11.3 \\
\hline Average / Total & 60.4 & 38.2 & 100 \\
\hline
\end{tabular}

Own estimates based on MINEDUC data. Includes only schools that receive public funding: public (municipal) and voucher schools. 
Table 3. Summary statistics

\begin{tabular}{|c|c|c|c|c|c|c|}
\hline \multirow[b]{2}{*}{ Variable: } & \multicolumn{2}{|c|}{$\begin{array}{c}\text { Total } \\
(\mathrm{N}=99,211)\end{array}$} & \multicolumn{2}{|c|}{$\begin{array}{c}\text { FDS } \\
(\mathrm{N}=32,157)\end{array}$} & \multicolumn{2}{|c|}{$\begin{array}{c}\text { Non-FDS } \\
(\mathrm{N}=67,054)\end{array}$} \\
\hline & Mean & Std. Dev. & Mean & Std. Dev. & Mean & Std. Dev. \\
\hline 2nd grade SIMCE score & 251.5 & 48.8 & 246.0 & 48.4 & 254.1 & 48.7 \\
\hline \multicolumn{7}{|l|}{ FDS measures } \\
\hline FDS enrollment (1st and 2nd grade) & 0.38 & 0.29 & 0.56 & 0.29 & 0.29 & 0.25 \\
\hline FD schools (1st and 2nd grade) & 0.28 & 0.25 & 0.45 & 0.29 & 0.20 & 0.17 \\
\hline Years of FDS exposure & 0.68 & 0.93 & 2.00 & 0.00 & 0.05 & 0.21 \\
\hline \multicolumn{7}{|l|}{ Individual characteristics } \\
\hline Boy & 0.50 & 0.50 & 0.50 & 0.50 & 0.50 & 0.50 \\
\hline Attended Pre-kinder & 0.93 & 0.25 & 0.91 & 0.29 & 0.94 & 0.23 \\
\hline Attended Kinder & 0.99 & 0.11 & 0.98 & 0.15 & 0.99 & 0.08 \\
\hline Repeated 1st grade & 0.04 & 0.19 & 0.05 & 0.22 & 0.03 & 0.17 \\
\hline Repeated 2nd grade & 0.03 & 0.16 & 0.04 & 0.19 & 0.02 & 0.15 \\
\hline New student in 2 nd grade & 0.12 & 0.32 & 0.12 & 0.32 & 0.11 & 0.32 \\
\hline \multicolumn{7}{|l|}{ Family characteristics } \\
\hline Father's years of schooling & 11.8 & 3.4 & 10.5 & 3.3 & 12.4 & 3.2 \\
\hline Mother's years of schooling & 11.9 & 3.2 & 10.8 & 3.3 & 12.5 & 3.1 \\
\hline Household income $<$ US $\$ 410 /$ month & 0.33 & 0.47 & 0.49 & 0.50 & 0.24 & 0.43 \\
\hline Household income US\$410-\$616/month & 0.22 & 0.41 & 0.23 & 0.42 & 0.22 & 0.41 \\
\hline Household income US $\$ 616-\$ 1,027 /$ month & 0.21 & 0.41 & 0.17 & 0.37 & 0.24 & 0.43 \\
\hline Household income $>\$ 1,027 /$ month & 0.24 & 0.43 & 0.11 & 0.32 & 0.30 & 0.46 \\
\hline
\end{tabular}


Table 3 (continued). Summary statistics

\begin{tabular}{|c|c|c|c|c|c|c|}
\hline \multirow[b]{2}{*}{ Variable: } & \multicolumn{2}{|c|}{$\begin{array}{c}\text { Total } \\
(\mathrm{N}=99,211)\end{array}$} & \multicolumn{2}{|c|}{$\begin{array}{c}\text { FDS } \\
(\mathrm{N}=32,157)\end{array}$} & \multicolumn{2}{|c|}{$\begin{array}{c}\text { Non-FDS } \\
(\mathrm{N}=67,054)\end{array}$} \\
\hline & Mean & Std. Dev. & Mean & Std. Dev. & Mean & Std. Dev \\
\hline \multicolumn{7}{|l|}{ School characteristics } \\
\hline Public (municipal) & 0.38 & 0.49 & 0.59 & 0.49 & 0.28 & 0.45 \\
\hline Voucher & 0.62 & 0.49 & 0.41 & 0.49 & 0.72 & 0.45 \\
\hline School enrollment & 834.1 & 584.1 & 834.1 & 584.1 & 912.5 & 602.0 \\
\hline Class size & 33.06 & 8.72 & 33.06 & 8.72 & 34.80 & 7.64 \\
\hline 4th grade math SIMCE - 2012 & 262.4 & 24.6 & 256.8 & 24.1 & 265.1 & 24.4 \\
\hline 4th grade math SIMCE - 2011 & 259.4 & 24.3 & 253.2 & 24.0 & 262.4 & 23.9 \\
\hline 4th grade language SIMCE - 2012 & 268.2 & 21.3 & 262.6 & 21.3 & 270.9 & 20.7 \\
\hline 4th grade language SIMCE - 2011 & 267.6 & 20.9 & 262.6 & 21.2 & 270.0 & 20.4 \\
\hline Rural school & 0.10 & 0.29 & 0.24 & 0.43 & 0.02 & 0.15 \\
\hline
\end{tabular}

Own estimates from data provided by the Education Quality Assurance Agency (Agencia de Calidad de la Educación). SIMCE data is 2nd grade SIMCE Reading Comprehension test given in 2012. Individual, family and school characteristics data are from supplementary questionnaires applied to parents and school administrators. 
Table 4. Baseline OLS and Instrumental variables estimates of the effect of FDS on Reading Comprehension skills.

Dependent variable: Average SIMCE score in Reading Comprehension test (2012)

\begin{tabular}{|c|c|c|c|}
\hline \multirow[b]{2}{*}{ Variables: } & \multirow[t]{2}{*}{ OLS } & \multicolumn{2}{|c|}{ IV } \\
\hline & & $\begin{array}{c}\text { 1st Stage: } \\
\text { FDS } \\
(2)\end{array}$ & $\begin{array}{c}\text { 2nd Stage } \\
\text { SIMCE Test } \\
\text { (3) }\end{array}$ \\
\hline FD school (in 1st and 2nd grade) & $\begin{array}{c}0.24 \\
(0.52)\end{array}$ & & $\begin{array}{l}6.82^{* *} \\
(2.93)\end{array}$ \\
\hline Municipal share - FD schools (1st and 2nd grade) & & $\begin{array}{c}0.41^{* * *} \\
(0.04)\end{array}$ & \\
\hline Boy & $\begin{array}{c}-9.62^{* * *} \\
(0.31)\end{array}$ & $\begin{array}{l}-0.00 \\
(0.00)\end{array}$ & $\begin{array}{c}-9.61^{* * *} \\
(0.31)\end{array}$ \\
\hline Attended Kinder & $\begin{array}{c}0.92 \\
(1.48)\end{array}$ & $\begin{array}{c}0.00 \\
(0.01)\end{array}$ & $\begin{array}{c}0.99 \\
(1.48)\end{array}$ \\
\hline Attended PreK & $\begin{array}{c}0.67 \\
(0.62)\end{array}$ & $\begin{array}{l}0.02^{* *} \\
(0.01)\end{array}$ & $\begin{array}{c}0.63 \\
(0.63)\end{array}$ \\
\hline Repeated 1st grade & $\begin{array}{c}-14.04^{* * *} \\
(0.80)\end{array}$ & $\begin{array}{c}0.01 \\
(0.01)\end{array}$ & $\begin{array}{c}-14.04^{* * *} \\
(0.80)\end{array}$ \\
\hline Repeated 2nd grade & $\begin{array}{c}-12.79 * * * \\
(0.94)\end{array}$ & $\begin{array}{c}0.00 \\
(0.01)\end{array}$ & $\begin{array}{c}-12.78^{* * *} \\
(0.94)\end{array}$ \\
\hline New student in 2nd & $\begin{array}{c}-1.30^{* * *} \\
(0.48)\end{array}$ & $\begin{array}{c}0.01 \\
(0.00)\end{array}$ & $\begin{array}{c}-1.30^{* * *} \\
(0.48)\end{array}$ \\
\hline Mother's years of education & $\begin{array}{c}1.10^{* * *} \\
(0.06)\end{array}$ & $\begin{array}{c}-0.01^{* * *} \\
(0.00)\end{array}$ & $\begin{array}{c}1.15^{* * *} \\
(0.06)\end{array}$ \\
\hline Father's years of education & $\begin{array}{c}0.87^{* * *} \\
(0.06)\end{array}$ & $\begin{array}{c}-0.01^{* * *} \\
(0.00)\end{array}$ & $\begin{array}{c}0.92^{* * *} \\
(0.06)\end{array}$ \\
\hline Income US\$422-\$632 & $\begin{array}{c}3.01^{* * *} \\
(0.43)\end{array}$ & $\begin{array}{c}-0.04^{* * *} \\
(0.00)\end{array}$ & $\begin{array}{c}3.30^{* * *} \\
(0.45)\end{array}$ \\
\hline Income US\$633-\$1,053 & $\begin{array}{c}5.00^{* * *} \\
(0.47)\end{array}$ & $\begin{array}{c}-0.06^{* * *} \\
(0.01)\end{array}$ & $\begin{array}{c}5.43^{* * *} \\
(0.51)\end{array}$ \\
\hline Income $>\$ 1,053$ & $\begin{array}{c}7.65^{* * *} \\
(0.53)\end{array}$ & $\begin{array}{c}-0.07^{* * *} \\
(0.01)\end{array}$ & $\begin{array}{c}8.19 * * * \\
(0.58)\end{array}$ \\
\hline Municipal school & $\begin{array}{c}-1.00^{* *} \\
(0.51)\end{array}$ & $\begin{array}{c}0.14^{* * *} \\
(0.02)\end{array}$ & $\begin{array}{c}-2.05^{* * *} \\
(0.71)\end{array}$ \\
\hline Total enrollment (school) & $\begin{array}{c}0.14^{* * *} \\
(0.05)\end{array}$ & $\begin{array}{c}0.00 \\
(0.00)\end{array}$ & $\begin{array}{c}0.14^{* * *} \\
(0.05)\end{array}$ \\
\hline Class size & $\begin{array}{l}-0.49 \\
(0.30)\end{array}$ & $\begin{array}{c}-0.03^{* * *} \\
(0.01)\end{array}$ & $\begin{array}{l}-0.29 \\
(0.32)\end{array}$ \\
\hline School 2012 SIMCE - 4th gr., Math & $\begin{array}{c}0.13^{* * *} \\
(0.02)\end{array}$ & $\begin{array}{c}0.00^{* * *} \\
(0.00)\end{array}$ & $\begin{array}{c}0.11^{* * *} \\
(0.02)\end{array}$ \\
\hline School 2011 SIMCE - 4th gr., Math & $\begin{array}{c}0.08^{* * *} \\
(0.02)\end{array}$ & $\begin{array}{c}-0.00 \\
(0.00)\end{array}$ & $\begin{array}{c}0.09 * * * \\
(0.02)\end{array}$ \\
\hline School 2012 SIMCE - 4th gr., Language & $\begin{array}{c}0.13^{* * *} \\
(0.02)\end{array}$ & $\begin{array}{c}-0.00^{* * *} \\
(0.00)\end{array}$ & $\begin{array}{c}0.15^{* * *} \\
(0.02)\end{array}$ \\
\hline
\end{tabular}


Table 4 (continued). Baseline OLS and Instrumental variables estimates of the effect of FDS on Reading Comprehension skills.

Dependent variable: Average SIMCE score in Reading Comprehension test (2012)

\begin{tabular}{lccc}
\hline & OLS & \multicolumn{2}{c}{ IV } \\
\cline { 2 - 4 } & & 1 st Stage: & 2nd Stage \\
& & FDS & SIMCE Test \\
Variables: & $(1)$ & $(2)$ & $(3)$ \\
\hline School 2011 SIMCE - 4th gr., Language & $0.11^{* * *}$ & -0.00 & $0.11^{* * *}$ \\
& $(0.02)$ & $(0.00)$ & $(0.02)$ \\
School in rural area & 0.54 & $0.29^{* * *}$ & -1.79 \\
& $(0.80)$ & $(0.03)$ & $(1.31)$ \\
Constant & $106.24^{* * *}$ & $0.84^{* * *}$ & $99.46^{* * *}$ \\
& $(3.82)$ & $(0.13)$ & $(4.89)$ \\
\hline Observations & 99,211 & 99,211 & 99,211 \\
R-squared & 0.11 & 0.31 & 0.11 \\
First Stage Statistics: & & & \\
$\quad$ R-squared (adjusted) & & 0.311 & \\
Partial R-squared (instrument) & & 0.037 & \\
$\quad$ F-statistic (instrument) & & 105.2 & \\
\hline Own estimates from data provided by the Education Quality Assurance Agency (Agencia de Calidad de la \\
Educación). SIMCE data is 2nd grade SIMCE Reading Comprehension test given in 2012. Individual, \\
family and school characteristics data are from supplementary questionnaires applied to parents and \\
school administrators. Additional controls: region fixed effects. Robust standard errors in parentheses. \\
*** p<0.01, ** p<0.05, * p<0.1
\end{tabular}


Table 5: Instrumental variables estimates of the effect of FDS on Reading Comprehension skills by sex, type of school and area. Dependent variable: average SIMCE score in Reading Comprehension test (2012)

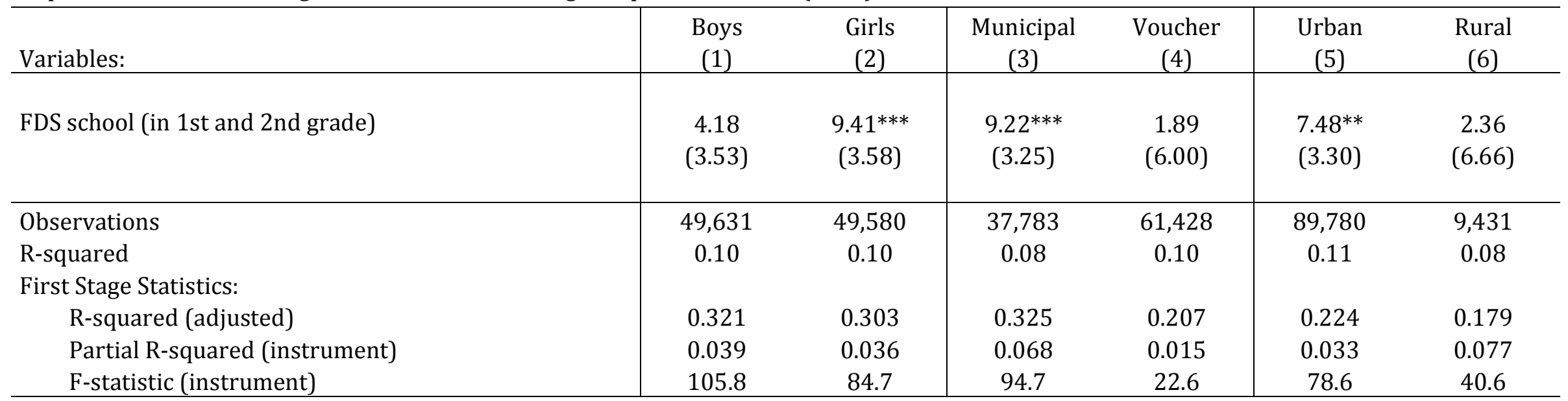

Table reports second stage estimates. Full first stage estimations available upon request. Own estimates from data provided by the Education Quality

Assurance Agency (Agencia de Calidad de la Educación). SIMCE data is 2nd grade SIMCE Reading Comprehension test given in 2012. Additional controls: child's sex, whether child attended pre-kinder or kinder, whether child repeated 1st or 2nd grade, new student in 2nd grade, mother and father's education, family income, dummy for municipal school, school enrollment, class size, school quality (proxied by 2011 and 2012 language and math SIMCE scores), dummy for rural location, and region fixed effects. Robust standard errors in parentheses. ${ }^{* *} \mathrm{p}<0.01,{ }^{* *} \mathrm{p}<0.05,{ }^{*} \mathrm{p}<0.1$ 
Table 6. Instrumental variables estimates of the effect of years of exposure to FDS on Reading Comprehension skills by sex, type of school and area.

Dependent variable: average SIMCE score in Reading Comprehension test (2012)

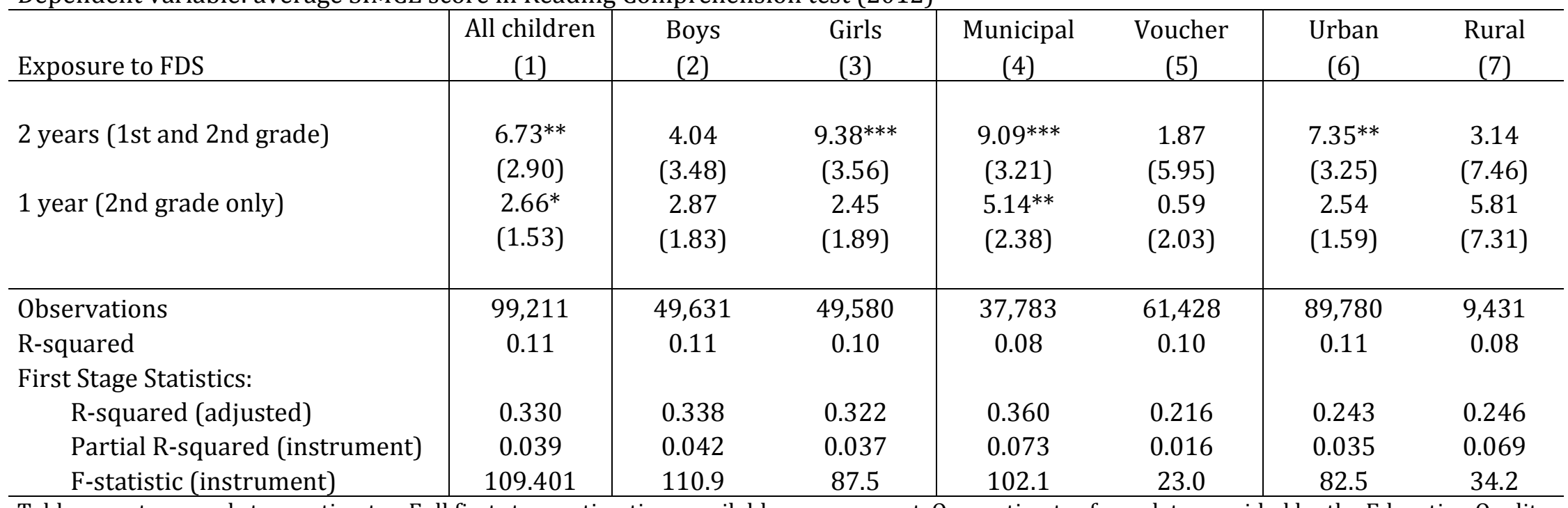

Table reports second stage estimates. Full first stage estimations available upon request. Own estimates from data provided by the Education Quality Assurance Agency (Agencia de Calidad de la Educación). SIMCE data is 2nd grade SIMCE Reading Comprehension test given in 2012. Additional controls: child's sex, whether child attended pre-kinder or kinder, whether child repeated 1st or 2nd grade, new student in 2nd grade, mother and father's education, family income, dummy for municipal school, school enrollment, class size, school quality (proxied by 2011 and 2012 language and math SIMCE scores), dummy for rural location, and region fixed effects. Robust standard errors in parentheses. ${ }^{* * *} \mathrm{p}<0.01,{ }^{* *} \mathrm{p}<0.05$, ${ }^{*} \mathrm{p}<0.1$ 